\title{
Pelatihan Peningkatan Ekonomi Masyarakat Desa Galang Baru Melalui Eco Wisata Bahari
}

\author{
Dian Lestari Siregar ${ }^{1 *}$, Anggia Dasa Putri ${ }^{2}$, Raymond $^{3}$ \\ ${ }^{1}$ Jurusan/Program Studi Teknik Informatika, Fakultas Ilmu Sosial dan Humaniora \\ ${ }^{2}$ Jurusan/Program Studi Akuntansi, Fakultas Ilmu Teknik dan komputer \\ ${ }^{3}$ Jurusan/Program Studi Manajemen, Fakultas Ekonomi \\ ${ }^{1,2}$ Universitas Putera batam \\ ${ }^{3}$ Universitas Batam \\ *e-mail :Dian.lestari@puterabatam.ac.id
}

\section{Informasi Artikel}

Diterima Redaksi: 30 Desember 2021

Revisi Akhir: 2 Januari 2022

Diterbitkan Online: 15 Januari 2022

Kata Kunci:

Pelatihan; Eco wisata: Ekonomi

\section{Abstrak}

Pulau Batam memiliki wilayah pesisir yang memiliki keindahan dan potensi besar dalam pengembangan pariwisata. Namun, perkembangan pariwisata di kota Batam memunculkan permasalahan baru yaitu pembangunan pariwisata tidak lagi memperhatikan kondisi lingkungan yang selaras dengan pembangunan ekonomi. Padahal sebagai tujuan destinasi wisata kota Batam adalah mengedepankan potensi alamnya yang indah berupa pantai dan keindahan laut. Salah satu dari banyak wilayah di Kota Batam yang memiliki potensi dalam pengembangan wisata bahari adalah wilayah pesisir Desa Galang Baru yang mempunyai potensi dan daya Tarik wisata khususnya wisata di bidang kemaritiman, seperti wisata pantai di tanjung cakang, Pulau sembur, Pulau korek, terumbu karang di pulau sembur dan pulau nguan, Hutan bakau di Tanjung Caking dan Pulau Nguan, serta makanan laut (seafood) di Galang Baru, Pulau Korek, Tanjung Cakang. Namun dibalik potensi wisata bahari di galang baru ternyata tidak dimanfaatkan secara optimal, untuk itu fokus program pengembangan desa mitra kali ini adalah pada empat aspek seperti pengembangan destinasi wisata, pengembangan Pemasaran pariwisata, pembentukan Industri pariwisata, serta pembentukan Kelembagaan pariwisata. hasil dari program ini yaitu memberikan pengetahuan bagi amsyarakat galang baru tentang eco Wisata bahari unggulan

\section{PENDAHULUAN}

Berdasarkan Keputusan Menteri Kelautan dan Perikanan Nomor: KEP.10/MEN/2002 tentang Pedoman Umum Perencanaan Pengelolaan Pesisir Terpadu, Wilayah Pesisir didefinisikan sebagai wilayah peralihan antara ekosistem darat dan laut yang saling berinteraksi, di mana ke arah laut 12 mil dari garis pantai untuk provinsi dan sepertiga dari wilayah laut itu (kewenangan provinsi) untuk kabupaten/kota dan ke arah darat batas administrasi kabupaten/kota. Sebagai negara maritim, Indonesia memiliki 42 Kota dan 181 Kabupaten yang berada di wilayah pesisir, populasi penduduk yang tinggal di pesisir tersebut mencapai 161 juta jiwa atau $60 \%$ dari total penduduk Indonesia. Melalui Undang-Undang Nomor 12 Tahun 2008 tentang Pemerintah Daerah, memberikan kesempatan bagi pemerintah daerah untuk mengelola dan mengoptimalkan potensi daerahnya secara mandiri.

Kota Batam adalah sebuah kota yang terletak di Provinsi Kepulauan 
Riau, Kota Batam memiliki luas wilayah daratan seluas $715 \mathrm{~km}^{2}$, sedangkan luas wilayah keseluruhan mencapai 1.570,35 km². (UU Nomor 53 Tahun 1999). Pulau Batam juga memiliki wilayah pesisir yang memiliki keindahan dan potensi besar dalam pengembangan pariwisata. Namun, perkembangan pariwisata di kota Batam memunculkan permasalahan baru yaitu pembangunan pariwisata tidak lagi memperhatikan kondisi lingkungan yang selaras dengan pembangunan ekonomi. Padahal sebagai tujuan destinasi wisata kota Batam adalah mengedepankan potensi alamnya yang indah yaitu berupa pantai dan laut . Oleh karena itu, pembangunan pariwisata di kota Batam hendaklah bertujuan untuk meningkatkan perekonomian perlu disertai upaya memperhatikan aspek lingkungan. Salah satu upaya pemanfaatan sumberdaya lokal yang optimal adalah dengan mengembangkan konsep Eco Wisata Bahari.

Menurut Permendagri No 33 tahun 2009 ekowisata merupakan potensi sumberdaya alam, lingkungan, serta keunikan alam dan budaya, yang dapat menjadi salah satu sektor unggulan daerah yang belum dikembangkan secara optimal, oleh karena itu eco wisata di definisikan sebagai kegiatan wisata alam di daerah yang bertanggungjawab dengan memperhatikan unsur pendidikan, pemahaman, dan dukungan terhadap usaha-usaha konservasi sumberdaya alam, serta peningkatan pendapatan masyarakat lokal, dalam pengembangan eco wisata diperlukan kegiatan perencanaan, pemanfaatan, dan pengendalian ecowisata. Salah satu jenis ecowisata menurut Permendagri No 33 tahun 2009 adalah ecowisata bahari

Menurut Undang-undang No. 10 Tahun 2009 tentang Kepariwisataan pengertian Wisata Bahari atau Tirta adalah usaha yang menyelenggarakan wisata dan olahraga air, termasuk penyediaan sarana dan prasarana serta jasa lainnya yang dikelola secara komersial di perairan laut, pantai, sungai, danau, dan waduk. Konsep wisata bahari didasarkan pada view, keunikan alam, karakteristik ekosistem, kekhasan seni budaya dan karaktersitik masyarakat sebagai kekuatan dasar yang dimiliki oleh masing-masing daerah. Pengembangan pariwisata yang berbasiskan kegiatan bahari dan pantai merupakan kegiatan yang berpotensi besar untuk dijadikan sebagai kegiatan utama penggerak ekonomi di kawasan pesisir dan lautan.

Berdasarkan data dari Badan Pusat Statistik kepulauan Riau (2017) Jumlah kunjungan wisatawan mancanegara yang berkunjung ke Kota Batam pada tahun 2016 ialah Sebesar 1.432.472 Jiwa dan menyumbang sebesar Rp106 miliar bagi PAD di Kota Batam Atau hanya $12.3 \%$ dari total PAD kota Batam sebesar Rp. 858 Miliar, Untuk itu peningkatan pemasukan, bidang pariwisata menjadi salah satu opsi yang menarik untuk meningkatkan pendapatan asli daerah di Kota Batam, Salah satu dari banyak wilayah di Kota Batam yang memiliki potensi dalam pengembangan wisata bahari adalah wilayah pesisir Desa Galang Baru. Wilayah yang berada di kecamatan Galang kota Batam ini berada pada koordinat $0^{0} 25-01^{0} 08-$ Lintang Utara dan $104^{0} 24$ Bujur timur ini berbatasan langsung dengan Kecamatan Bulang di sebelah barat dan Kecamatan Senayang di sebelah selatan dan Kecamatan Tanjung Pinang disebelah timur dan Kecamatan Bintan Utara di sebelah utara, galang baru memiliki total peduduk sebesar 2,944 jiwa, dengan Total luas Desa galang Baru sebesar $394,681 \mathrm{~km}^{2}$, dimana luas daratan sebesar $50,287 \mathrm{~km}^{2}$ dan total luas laut sebesar $344,393 \mathrm{~km}^{2}$, 
Tergambar jelas bahwa sebagian besar wilayah galang baru berbentuk kepulauan, pulau-pulau kecil di sekitar desa Galang Baru, mempunyai banyak sekali potensi dan daya Tarik wisata khususnya wisata di bidang kemaritiman, seperti wisata pantai di tanjung cakang, Pulau sembur, Pulau korek, terumbu karang di pulau sembur dan pulau nguan, Hutan bakau di Tanjung Caking dan Pulau Nguan, serta makanan laut (seafood) di Galang Baru, Pulau Korek, Tanjung Cakang. Dengan posisi kota Batam yang secara geografis berbatasan langsung dengan beberapa Negara seperti Singapura dan Malaysia akan menjadikan potensi pariwisata di galang baru menjadi objek atau destinasi baru yang menarik bagi masyarakat maupun turis dari manca Negara.

Namun dibalik potensi wisata bahari di galang baru ternyata tidak dimanfaatkan secara optimal, hal ini tergambar dengan kurangnya minat masyarakat untuk berkunjung ke destinasi wisata di galang baru, banyak faktor yang melandasi hal tersebut antara lain :

1. Kurangnya pengembangan destinasi wisata di galang baru yang diakibatkan susahnya akses maupun kurangnya sarana pendukung pada destinasi wisata yang dituju.

2. Tidak adanya rencana Pemasaran pariwisata yang dibuat oleh masyarakat galang baru yang dikarenakan tidak adanya akses maupun dukungan pihak luar dalam pengembangan maupun bantuan akses pemasaran di Galang baru

3. Tidak terbentuknya Industri pariwisata digalang baru yang dikarenakan tidak adanya daya saing maupun kemitraan yang mendukung pariwisata di galang baru

4. Tidak adanya Kelembagaan pariwisata yang terbentuk di galang baru sehingga tidak terbentuk manajemen pengelolaan pariwisata di galang baru

Dampak dari permasalahan tersebut menyebabkan rendahnya tingkat pertumbuhan ekonomi masyarakat di galang baru, hal ini sangat disayangkan karena mengacu pada rencana strategis yang dituangkan dalam rencana pembangunan jangka menengah daerah (RPJMD) Kota Batam yaitu :

1. Reformasi birokrasi dan tata kelola pemerintahan yang baik.

2. Peningkatan kualitas pengembangan dan pembangunan infrastruktur wilayah dan penataan transportasi

3. Peningkatan kualitas sumber daya masyarakat

4. Peningkatan kualitas produk kemaritiman dan kepariwisataan dengan fokus pada jasa dan perdagangan

5. Perlindungan dan pengelolaan lingkungan hidup

6. Pengurangan ketimpangan ekonomi dan peningkatan daya saing, perluasan kesempatan kerja, serta penanggulangan kemiskinan

7. Pengembangan teknologi informasi dan telekomunikasi.

Dari rencana pembangunan jangka menengah daerah (RPJMD) kota Batam Tergambar jelas bahwa salah satu fokus utama dalam pembangunan kota Batam adalah peningkatan kualitas produk kemaritiman dan kepariwisataan, serta pengurangan ketimpangan ekonomi dan peningkatan daya saing, perluasan kerja dan penanggulangan kemiskinan, untuk itu Guna mengatasi permasalah di galang baru tersebut, maka tujuan umum dari program pengabdian ini adalah sebagai berikut:

1. Pengembangan Destinasi wisata di galang baru

2. Pembuatan Kelembagaan pariwisata di galang baru 
2. METODE

Metode pelaksanaan yang akan dijalankan oleh Tim Pelaksana memiliki akan terdiri dari beberapa tahap pelaksanaan. Pada tahap awal Tim Pelaksana telah melakukan observasi awal di lokasi desa galang baru sehingga mendapatkan beberapa data terkait pengelolaan ecowisata bahari di desa galang baru termasuk sarana transportasi penunjang di desa galang baru. Pelaksanaan akan diawali dengan melakukan perancangan dan penerapan aspek aspek kepariwisataan, dimana pada tahap ini akan didasarkan pada empat aspek dimana aspek tersebut antara lain :

1. Destinasi wisata

2. Pemasaran pariwisata

3. Industri pariwisata

4. Kelembagaan pariwisata

Dari keempat aspek tersebut akan menjadi tolak ukur pengembangan kepariwisataan di desa galang baru, dimana tolak ukur untuk pengembangan pariwisata bahari di galang baru. Tahapan awal akan dimulai dengan melakukan observasi yang telah dilakukan. Pada observasi tersebut Tim Pelaksana melakukan pengamatan, jajak pendapat dan diskusi antara Tim Pelaksana dengan masyarakat dan kelompok masyarakat di desa galang baru, hasil obeservasi tersebut tim pelaksana mendapat berbagai informasi tentang kendala serta permasalahan berkaitan pengembangan pariwisata di desa galang baru

\section{HASIL DAN PEMBAHASAN}

Dengan informasi yang didapat, Tim Pelaksana dan mitra kelompok sepakat untuk melakukan perbaikan dalam tahapan operasional, berikut adalah Pelaksanaan pengabdian di Desa Galang Baru :

1. Metode Pendekatan

Metode pendekatan yang dilakukan oleh Tim Pelaksana pada tahapan observasi awal terkait proses produksi adalah melalui focus grup discussion (FGD) dan membahas keseluruhan proses.

2. Prosedur Kerja

Masing-masing tahapan yang dilaksanakan oleh Tim Pelaksana mengacu kepada tahapan kerja sebagai berikut:

a. Tahapan Perancangan dan Penerapan

Tahapan perancangan ini merupakan tahapan realisasi dari hasil FGD dimana luaran dari kegiatan tersebut adalah data dan informasi dari kelompok usaha masyarakat galang baru, Data dan informasi yang didapatkan dari FGD akan diolah dan selanjutnya akan dilakukan pembentukan konsep alat serta bentuk pelatihan baik pelatihan operasional alat serta pelatihan manajemen bagi masyarakat galang baru, Berikut tahapan - tahapan perancangan dan penerapan kegiatan yang akan diberikan kepada masyarakat galang baru sebagai berikut:

b. Pembentukan Rancangan

Operasional

Pada tahapan ini dimulai dengan jalan merancang ulang prosedur operasional secara sederhana dan tidak mengubah secara total yang dilakukan oleh masyarakat. Perubahan prosedur operasional ini dilakukan untuk peningkatan produktifitas masyarakat sehingga dapat menigkatkan konsep pengembangan pariwisata di desa galang baru, Langkah selanjutnya adalah melakukan pelatihan bagi mitra masyarakat galang aru. Pelatihan yang dimaksud dalam hal ini adalah pelatihan tata cara operasionalisasi yang didasarkan pada buku manual yang telah dirancang oleh Tim.

c. Tahapan Pendampingan Operasional Pada tahapan ini Pendampingan yang dilakukan oleh tim pelaksana akan melihat dan menilai untuk mendapatkan perbandingan produktifitas kerja kelompok binaan dari sebelum dilakukan perbaikan dengan setelah 
dilakukan penerapan hasil perbaikan. Dari hasil penilaian perbandingan yang didapat digunakan untuk dasar perbaikan dan pembenahan apabila ditemukan bagian atau tahapan yang belum dapat berjalan secara optimal dalam mendukung peningkatan produktifitas kelompok masyarakat binaan. Selain itu Tim akan turut mengundang stakeholder maupun instansi terkait dengan pengembangan pariwisata di desa galang baru.

\section{KESIMPULAN}

Kesimpulan yang dapat ditarik dari adanya kegiatan Pelatihan yang telah berlangsung adalah:

1. Memacu dan meningkatkan keinginan pemilik usaha untuk memahami dan menerapkan materi untuk meningkatkan kegiatan usahanya

2. Pengembangan dan pembinaan pada para UMKM sebagai upaya untuk meningkatkan hasil usaha yang mereka peroleh

3. Kegiatan ini sebagai kegiatan dalam meningkatkan produktivitas kerja dengan cara membina dan memonitoring kegiatan

\section{SARAN}

Kegiatan serupa dapat terus dilaksakana secara berkelanjutan dengan pembahasan materi yang lebih luas lagi, Dibutuhkannya dukungan tekhnologi seperti LCD guna mempermudah penyampaian materi, Diharapkan agar pengusaha lebih aktif dalam menggali ilmu pengetahuan dalam hal pencatatan laporan keuangan usaha baik dari lembaga-lembaga tertentu lainnya.

\section{UCAPAN TERIMA KASIH}

Ucapan terimakasih penulis sampaikan kepada Universitas Putera Batam khususnya Lembaga Penelitian dan Pengabdian Masyarakat yang telah membantu kegiatan ini. Tidak lupa disampaikan kepada masyarakat galang baru selaku UMKM yang telah memberikan support dan membantu kegiatan pengabdian masyarakat ini.

\section{REFERENSI}

[1] Tomi, "Pertumbuhan ekonomi kepri menurun," BatamTimes.co, 2017. [Online]. Available: http://www.batamtimes.co. [Accessed: 04-Feb-2018].

[2] I. Faruq, "Cara mengelola keuangan bisnis dan usaha secara efektif," Centrausaha.com, 2018. [Online]. Available: https://centrausaha.com. [Accessed: 02-Feb-2018]. 